\title{
The Role of Strategic Management on Exporting Performance: A Case Study of Iranian Firms
}

\author{
Homa Doroudi \\ Department of Business Management, Zanjan Branch, Islamic Azad University, Zanjan, \\ Iran \\ Maryam Gharakhanlou (Corresponding author) \\ Department of Business Management, Zanjan Branch, Islamic Azad University, Zanjan, \\ Iran \\ E-mail: M.gharakhanloo@gmail.com
}

Received: September 3, 2015 Accepted: September 13, 2015 Published: June 6, 2016

doi:10.5296/bms.v7i1.9557ＵRL: http://dx.doi.org/10.5296/bms.v7i1.9557

\begin{abstract}
The current study investigates the strategy implementation of Iranian export performance, in Februy, 2015. It was conducted among 150 managers of Iranian exporting firms in order to find any significant relationship between strategy management and success in exporting performance. The methodological approach adopted for this study is Structural Equational Model (SEM) approach. It was processed in two sections (Pilot and Main study).The salient instrument of the study was questionnaire. The data were coded in SPSS (Statistical Package for Social Science, Version 22) and Lisrel (Version 8.8) Software. Three types of analyses were conducted to identify any significant relationship between them. The results revealed that there are significant relationship in most of strategies and exporting performance.
\end{abstract}

Keywords: Entrepreneurial orientation, Marketing capabilities, Globalization 


\section{Introduction}

According to the management education, globalization is one of the most significant forces of change for business. It has commended the attention of legions of writers, consultants, and advisers who have stepped forward to assist managers, as they wrestle with globalization.Globalization is a widely used term, intended to describe the recent and rapid process of intercontinental economics, Social, and political integration. This world wide integration allows people to communicate, travel, and invest internationally, and helps companies market their produces widely, acquire capital and human and material resources more efficiently, share advanced technology, and enjoy economics of scale (Wells, Shuey, Kielky, 2001). It is the result of rational and natural processes. Globalization expands economic freedom and spurs competition, it raises the productivity and living standards of people in countries that open themselves to the global marketplace (Cato Institute, 2006).

The evolution of entreprenurship combined with globalization of the business environment has created new opportunities and given rise to new managerial challenges. This rapidly evolving technology-and information-intensive environment, for example, requires new techniques both for protecting intellectual property and for exploiting it globally (Etemad, Wright, 2003). Throughout the $1990 \mathrm{~s}$, it was very apparent that the small to medium-sized enterprise (SME), and the multinational corporation (MNL) were being encouraged to consider their international competitiveness and where they were positioned in the marketplace (Chell, 2001).

The strategic management process is the full set of commitments, decisions, and actions required for a firm to achieve strategic competitiveness. The firm's first step in the process is to analyze its external and internal environments to determine its resources, capabilities, and core competencies the source of its "strategic inputs" (Hitt \& Robert, 2009).Within the scope of strategic management, entrepreneurship is widly accepted as a salient component in the process of development and economic growth (Covin \& Lumpkin 2011; Miller 2011; Covin $\&$ Wales 2012). Large gaps remain in our knowledge about the globalization of management education: scale, scope, curriculum, modes of collaboration, and impact.Miller (1983) was the first to propose the operationalisation of the EO (Entreprenurship Orientation) construct as comprising a firm's innovativeness, risk-taking and proactiveness. To date, however, there is no single definition of entrepreneurship, since different authors give different perspectives and definitions (Schaper \& Volery 2004; Landström 2005; Kuratko 2009). This means that entrepreneurship involves the risk of buying at certain prices and selling at uncertain prices.

EO differ from a manager on various counts, the former is owner, whereas later as servent (kumar, 2003). EO represents specific organisational-level behaviour that provides a basis for entrepreneurial actions (Rauch et al. 2009; Covin \& Wales 2012). The resource based theories focusing on dependent capabilities of companies and organizations (Weerfell, 1984; Barney, 1991) have come to develop as strategy theory frameworks from the viewpoints of microeconomics and organization economic. 


\section{Problem Statements}

In order to get global recognition in an international market as well as for ultimate success and reputation, globalization, is essential and inevitable factor for any firm's strategy (Welch \& Luostarinen, 1988). Owing to the particular resource endowments and export characteristics, the oil exporting developing counties face a number of rather special developments requiring tailor-made strategies(Amuzegar, 2008). Although Iranian authorities always emphasized the importance non-oil exports to reduce the country's reliance on oil revenues (Amid \& Hadjikhani, 2009). Yet, trade policies were more passive with respect to exports. There are several reasons that cast doubt on the sustainability of the improvement. First of all, an increase in oil prices, and consequently oil revenues, can significantly reduce the nation of non-oil exports to oil exports.

Another points is concerned with the investments in chemical petrochemical area. Consequently, Providing sizable domestic market. Therefore, this study carried out to appraise the role management strategies in associating of exporting performance.

\section{Literature Review and Formulation of Hypothesis}

Exporting is an important strategy for many companies. It is a way to gain access to a wider variety of goods for less than the cost of producing them at home. The reasons for exporting domestic production are to access new market, technology, to overcome domestic production saturation and to explore new avenus of marketing (Alkhafaji,1995). Exporting can be involved in direct and indirect exporting. Generally, direct exporting is more involved, more expensive and riskier than indirect.If indigenous firms from developing countries are to move to the internationalization of marketing activities or begin their export activities with these actibvities conducted in-house, they are confronted with the problem of how to gain access to export market (Wint,1995).

Absorptive capacity (ACAP) is a source of competitive advantage and plays a central role in a firm to develop competencies, capabilities, innovation and foster knowledge creation ability (Cohen and Levinthal, 1990). Furthermore, ACAP has a positive effect on strategic alliance success, and it would be an influential force to empower a firm's relational capabilities (Lane and Lubatkin, 1998), inter-organizational learning (Lane and Lubatkin, 1998; Lane et al., 2001) and intra-firm knowledge transfer (Szulanski, 1996).

Technological techniques complementing the evolution of market and human needs with an understanding of technology's future Capabilities do exist (Couillard, 2002).Successive steps of probing and learning gather additional new knowledge, which stimulates increase in performance and new insights on the products's application (Lynn et al, 1996, Tschirky et al. 2000).

In international scale, Solberg (1977) in a sample of 173 Norwegian exporting companies and by exploring four various contexts of performance ambiguity involving cultural distance (external uncertainty) and product complexity (internal uncertainty) tried to analyses 
relational drivers' effect on relationship quality between trading partners - exporters and their distributors. The result of his study confirmed that product complexity and cultural distance are two salient factors used by exporters in creating relationship quality with their foreign sales intermediaries that moderate the role of relational mechanisms.

As Iranian context, Jalali in a sample of 141 Greek firms tried to examine the relationship between export barriers and the export performance targeting the Iranian market. Using expert opinions, 18 variables were identified. A structured questionnaire was applied to and exploratory and confirmatory factor analyses were used to categorize variables in 6 dimensions. Then, a structural equation model was developed to determine which dimension has a greater effect on export performance. The result of his study identified the operational dimension (0.65), environmental dimension (0.60), financial dimension (0.58), source dimension (0.44), legal dimension (0.35) and logistic dimension (0.27) as effective export barriers to the export performance of Greek firms.

To date, there is no significant study of EO and its association with performance within the context of Iranian firms, particularly in the exporting. A large number of empirical studies have reported that EO has a positive effect on firm performance (e.g., Wiklund \& Shepherd 2003; Keh, Nguyen \& Ng 2007; Li, Huang \& Tsai 2009). However, other researchers (e.g., Covin, Slevin \& Schultz 1994; Slater \& Narver 2000; Lee, Lee \& Pennings 2001; Hughes \& Morgan 2007) were unable to identify a positive and significant relationship between EO and firm performance. These mixed findings indicate that EO may, but not always, lead to superior performance (Kusumawardhani, McCarthy \& Perera 2009).

Based on the review of the related literature, it is hypothesized that:

1. There is a significant positive effect between technology learning and Iranian Exporting performance through manufacturing flexibility capacity.

2. There is a significant positive effect between technology learning and Iranian exporting performance through Innovative capability.

3. There is a significant positive effect between market learning and Iranian exporting performance through innovative capability.

4. There is a significant positive effect between market learning and Iranian exporting performance trough market expansion adaptation capability?

5. There is a significant positive effect between social learning and Iranian Exporting performance through market expansion-adaptation capability.

6. There is a significant positive effect between Manufacturing Flexibility Capability and Market Expansion Adaptation Capability through Innovative Capacity. 


\section{Macrothink}

\section{Method}

\subsection{Procedure}

At whole, the procedure was carried out in two sections (pilot and main study) and Iranian exporting firms were participated in this study. A total of 150 questionnaires were distributed face-to-face to owners/managers of Iranian exporting firms. The researcher mentioned to the participants to fill out both sections of the questionnaires, one section related to the demographic information another related to the strategies that the participants may have recently used. This quantitative data was analysed using explanatory factor analysis, confirmatory factor analysis and structural equation modeling (SEM).

\subsection{Pilot study}

The researcher completed a pilot study with 25 firms for considering usability and reliability of questionnaire in order that tool can be administered without any difficulty in the target firms, also to avoid any difficulty which will encounter during the main study.

\subsection{Implications for the Main Study}

All of exporting firms were eager to fill out questionnaire and any of them felt impatient during administration. Some managers suggested that questionnaire should be corporate with oral assistance in order to avoid misunderstanding of the test instructions. Considering layout of test a few manager suggested that the layout of the test should be set attractively to draw attention of the tastes.

\subsection{Population}

Data were collected from 150 high involvement Iranian exporting firms' informants. The educational background of the sample varied as shown in Table 2.1

Table 1. Descriptive statistic of the sample

\begin{tabular}{|l|l|l|}
\hline Destribution & Frequency & $\%$ \\
\hline Gender & & \\
\hline Male & 128 & 77.00 \\
\hline Female & 23 & 33.00 \\
\hline
\end{tabular}

\section{Instrument}

\section{Questionnaire}

The data were collected using a structured questionnaire that included sections on Learning technology, Market learning, Social learning, Manufacturing Flexibility Capacity, Entrepreneurship Orientation, Innovative capability, Market Expansion Adaptation capability and Export Performance. It consisted of 27 items figured out in eight categories by 5 point Likert Scale. To ensure that the questionnaire content and design would be easily and unambiguously understood by the respondents, it was pre-tested by 7 experts (Four academic 
professors in international business field, three consultants of exporting and foreign business) and the questionnaire revised in according of their comments.As table 2.2 illustrates, Cronbach Alpha were in acceptable level for all category of questionnaire.

Table 2. Category of questionnaire

\begin{tabular}{lcc}
\hline Category & Number of Items & Cronbach Alpha \\
\hline Tecnology Learning & 4 & 0.877 \\
Market Learning & 4 & 0.870 \\
Social Learning & 4 & 0.863 \\
Manufacturing Flexibility & 3 & 0.898 \\
Innovative Capability & 3 & 0.804 \\
Market Expansion & 3 & 0.887 \\
Entrepreneurship & 3 & 0.866 \\
Export Performance & 3 & 0.809 \\
\hline
\end{tabular}

\section{Results}

Toward the aim of study, multivariate analysis (SEM) was used. These is no significant effect between the laten variable if, $\mathrm{T}$ value are between $(-1.96<\mathrm{T}$-value $<1.96)$. The normality of data distribution was assessed by examining its skewness and kurtosis. The absolute values of standardised skew or kurtosis indices were used to assess the linearity of the variables, although there is fewer consensuses regarding the use of indices to assess normality (Kline 2005).

Table 3. Descriptive statistics of categories

\begin{tabular}{|l|l|l|l|l|}
\hline Strategies & Mean & SD & Skewness & Kurtosis \\
\hline $\begin{array}{l}\text { Technology } \\
\text { Learning }\end{array}$ & 3.45 & 0.89 & 0.89 & 1.76 \\
\hline $\begin{array}{l}\text { Market } \\
\text { Learning }\end{array}$ & 3.82 & 0.74 & -1.33 & 0.62 \\
\hline Social Learning & 2.73 & 1.33 & 1.90 & 0.45 \\
\hline $\begin{array}{l}\text { Maufacturing } \\
\text { Capability }\end{array}$ & 4.53 & 1.08 & 0.87 & 1.34 \\
\hline $\begin{array}{l}\text { Innovation } \\
\text { Capability }\end{array}$ & 2.58 & 1.76 & 1.35 & -.45 \\
\hline
\end{tabular}

\section{Exploratory Factor Analysis}

Exploratory factor analysis (EFA) is intended to explore the data if the links between the 


\section{Macrothink}

Business Management and Strategy

ISSN 2157-6068

2016, Vol. 7, No. 1

observed and latent variables are unknown or uncertain (Byrne 2010; Hair et al. 2010). The extent of relationships among all measured variables to every factor is represented by factor loadings. A set of highly inter-correlated measured variables will be grouped into a distinct factor. EFA provides the researcher with information about the numbers of factors that best represent the data. This means that in EFA, statistical results, not theory, derive the factors (Hair et al. 2010).

Table 4. KMO and Bartlett's Test

\begin{tabular}{|l|l|}
\hline Kaiser-Mayer-Olkin & 0.832 \\
\hline Approx.Chi-square & 1132.79 \\
\hline DF & 345 \\
\hline Sig & 0.000 \\
\hline
\end{tabular}

The Kaiser-Meyer-Olkin value was 0.832 , which exceeded the recommended value of 0.60 . This indicates that more than $\% 83$ of variance in the measured variables is common variance. The Bartlett's Test of Sphericity value from the data set showed statistical significance (chi-square with degrees of freedom $1132=79$, sig $=.000$ ). This means that there were sufficient relationships among the variables to investigate. The Kaiser-Meyer-Olkin and Bartlett's Test of Sphericity values suggest that the data set in this study was suitable for factor analysis.

Table 5. Principal component analysis, $(\mathrm{n}=150)$

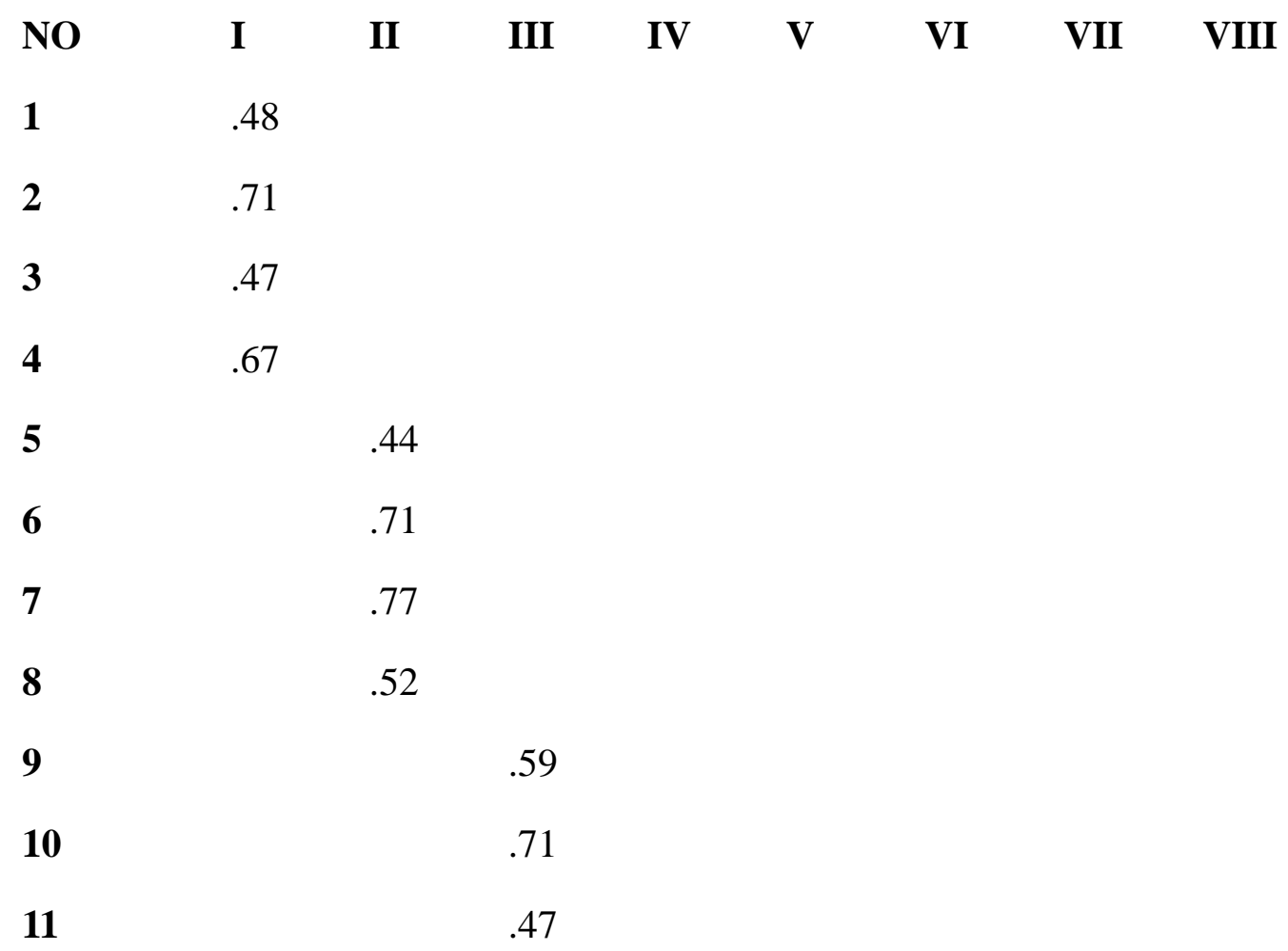


Note. I=Tech.Lear, II=Mark.Lea, III=Soci.Lea, IV=Manu Flex, V=Innova, VI=Market. Expa, VII=Entrprenurship, VIII=Export.Per

Data questions are loaded into eight categories (Table 3.2). Four items loaded on category one (technology learning). These items were related to primary instrument that closes the technological gap between developing countries and the international technological frontier. By and large, this process facilitates developing countries to increase productivity levels, strengthen international competitiveness, and enter new markets or market segments for higher value-added goods (Warren, 2007). There were four items loading on second category (Market Learning). This factor reflected the understanding of customer needs requires responsiveness from the firm's side in order to develop certain activities, processes, procedures and marketing strategies. . Thus, it was named "market Learning". Four items loaded on third category (Social Learning). This factor indicated social capital such as networks, informal connections, inter-firm relationships, and managerial ties are considered a critical resource base for international activities at small Southeast Asian firms (Ellis, 2010; Pollard \& Jemicz, 2010). Also, three items loaded on category four (Manufacturing Capability) which relate to the dimension of cost, quality, flexibility, and delivery. Four items loaded on category 5 (Innovative Capability) these items were related to tools which support 


\section{Macrothink}

local firms in becoming or staying competitive in the global market. In addition, three items were loaded in category six (Market Expansion Adaptation Capability). Also, three items loaded in Entrepreneurship. Finally, three items loaded on Factor eight (Export Performance) and also items were removed from the structure that are, loadings lower than .30 or cross loaded on other.

\section{Goodness- Of- Fit Indices}

The fitness of the model was assessed through several indices, through Chi-Square statistics, the Goodness of Fit Index (GFI), the Adjusted Goodness of Fit Index (AGFI), and Root Mean Square Error of Approximation (RMSEA) in order to verify overall structure of research model.

Table 6. Goodness of fit indices for model

\begin{tabular}{lccccc}
\hline & $\chi^{2}$ & GFI & AGFI & CFI & RMSEA \\
\hline Construct & 11.52 & .96 & .96 & .91 & .31 \\
\hline
\end{tabular}

According to Wang (2012) SEM provides powerful means of simultaneously examining casual relationship and the quality of measurement. As Table 3.3 shows the goodness of fit index (GFI) in this case .96, that is above acceptable range (criterion GFI $>95$ ). The adjusted goodness of fit index (AGFI) is .96 which means that values are greater than cut-off point. The comparative fit index (CFI) in this case is .91 more than the acceptable level .90. Finally root mean square error of Approximation (RMSEA) value is .31 which indicates a good fit.

\section{Evaluation of Structural Model}

The main aim of this investigation was to determine export performance with respect the role of implementation of management strategic. 


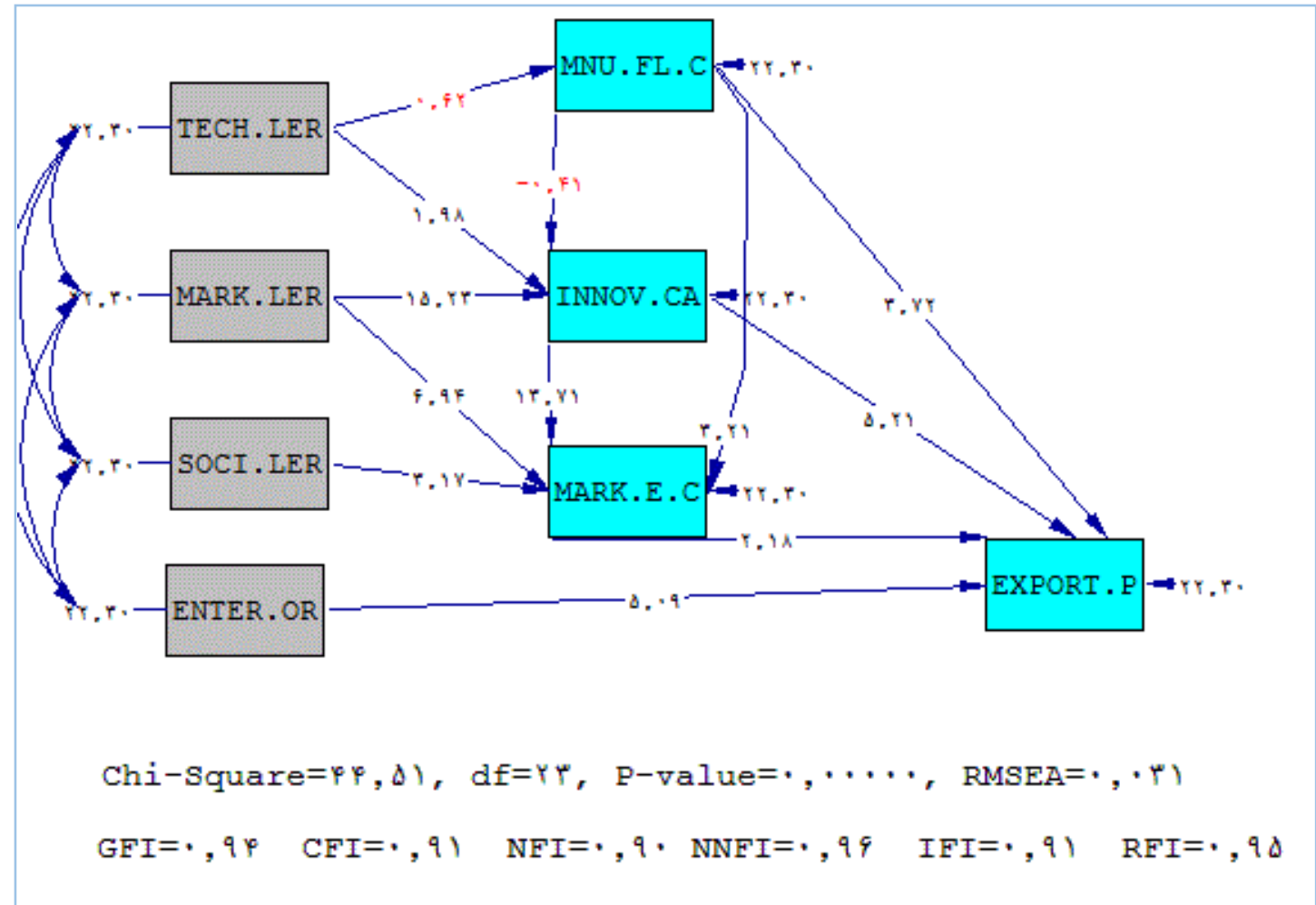

Figure 1. Path Diagram of Strategy dimensions and export-Performance Relationship in tvalues

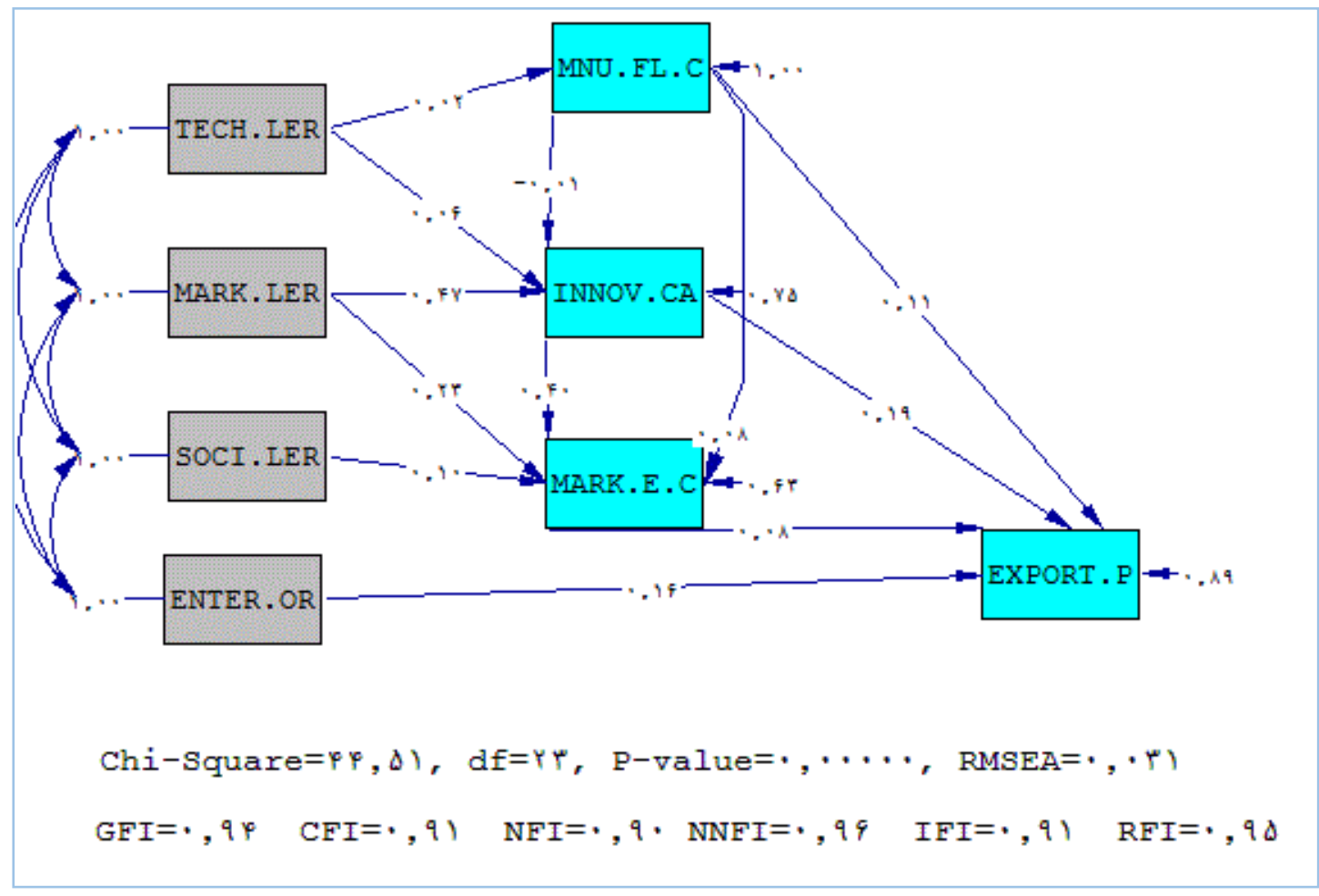

Figure 2. Path Diagram of Strategy dimensions and export-Performance Relationship in standard solution 
The seven Strategy dimensions (Tecnology Learning, Market Learning, Social Learning Manufacturing Flexibility Capability, Innovative Capability, Entrprenurship and Market Expansion Adaptation Capability) are exogenous constructs (independent variables), while Exporting performance is an endogenous construct (dependent variable). Hence, conceptual framework of stud consists of six hypotheses. After testing the measurement model, it was needed to test the structural model to examine the proposed model and verifying the significant relation between the latent variables,. This study tested the model considering the intensity of the path coefficients and the variance explained of the dependent variables.

\section{Conclusion}

The present study was conducted in a systematic and non-judgmental manner. It was contributed to the field of management strategies in respect of exporting firms. The adopted model for this study initially tested with American exporting firms originally proposed by Rodriguez (2009), is now extended and validated in a sample of high involvement of Iranian exporting firms. At whole, all of variable had a positive relation on exporting performance. In particular, the path coefficients direct causal effect from technology learning to manuafacturing flexibility is 0.62 Thus, hypothesis $\mathrm{H} 1$ is rejected, manager perceive a negative relationship between technology learning through manufacturing flexibility capability in exporting firms. The direct effect from technology learning through innovative capability is 1.98 . Thus there is a positive relationship between technology learning and innovation capability on exporting performance, so the second hypothesis of study is accepted. The direct effect market learning on innovation capability is 15.23.Thus H3 is accepted. As Hypothesized, market learning through Marketing Expansion is 6.94 on exporting performance and also, $\mathrm{H} 4$ is accepted. Regarding social learning, it has a direct impact 3.17 through market expansion-adaptation and H5 is accepted. Lastly, Manufacturing Flexibility capabiliy has a direct impact -0.41 on market expansion-adaptation. Thus sixth hypothesis was rejected.

The finding show strong support for all the hypotheses considered in this study. Overall, the model suggests that high involvement exporting firms require a blend of absorptive and higher order dynamic capabilities to develop their international competitiveness. The nature of the global economy reflects the realities of a hypercompetitive business environmental and challenges individuals firms to seriously evaluate the markets in which they will complete(Michael, Hitt; Robert, Hoskisson, 2004 ). Iranian firms engaging in globalization of their operations must make culturally sensitive decision when using strategic management process. They must engage in globalization and make culturally sensitive decision when using the strategic management process. To be strategically flexible on a continuing basis and to gain the competitive benefits of such flexibility, Iranian firms has to develop the capacity to learn continuous learning to provide the firms with new and up-to-date skill sets, which allow it to adopt to its environment as it encounters changes.

The last, findings of this study suggest that some management theories, particularly entrepreneurship theory that have been developed in the western world or developed 
countries may need to be adapted when applied in other cultures or emerging economies, such as Iranians.

\section{Limitation}

The finding show strong support for all the hypotheses considered in this study. Overall, the model suggests that high involvement exporting firms require a blend of absorptive and higher order dynamic capabilities to develop their international competitiveness. The nature of the global economy reflects the realities of a hypercompetitive business environmental and challenges individuals firms to seriously evaluate the markets in which they will complete (Michael, Hitt; Robert, Hoskisson, 2004 ). Iranian firms engaging in globalization of their operations must make culturally sensitive decision when using strategic management process.

Even though the EO scale used in the questionnaire was adapted from previous research and translated into Persian, some questions relating to EO dimensions as well as firm performance seemed not to relate to the respondents' activities.

\section{Recommendations for Future Research}

This study is an empirical study on implementation of management strategies conducted in the Iranian context. Therefore, its findings need to be confirmed. Further research can replicate this study, with some relevant adjustments to the research methodology in different cities in Iran with different participation. It could not only provide more information about the phenomena being studied but also identify whether particular EO dimensions are influenced by the nature of the exporting as well as culture, as suggested by the findings in this study. From a methodological point of view, this study is limited by self-report nature of the data that relies entirely on the perspective of one person.

\section{References}

Alkhafaji, A. F. (2003). Strategic Management. Formulation, evaluation and control in a dynamic environment, USA: The Haworth Press.

Barney, J. B. (1986). Strategic factor markets: Expectations, lucks, and business strategy. Management Science, 17(1), 99-120.

Bell, J., McNaughton R., \& Young, S. (2001). 'Born-Again Global' Firms. An Extension to The 'Born-Global' Phenomenon, Journal of International Management, 7, 173-89. http://dx.doi.org/10.1016/S1075-4253(01)00043-6

Cantillon, R. (1755/1999). Essai sur la nature du commerce en général, London: MacMillan.

Cavusgil, S. T., \& A. Das. (1997). Methodology Issues in Cross Cultural Sourcing Research a Primer. Marketing Intelligence and Planning, 15(5), 213. DOI: $10.1108 / 02634509710177279$

Cavusgil, S. T., \& Kirpalani, M. V. H. (1993). —Introducing Products into Export Markets: Success Factorsl. Journal of Business Research, 27, 1-15. [Online] Available: http: // 
citeseerx.ist.psu. edu / viewdoc/download?doi=10.1.1.199.8824\&rep=rep1\&type=pdf.

Chell, E., Haworth, J., \& Brearley, S. (1991). The Entrepreneurial Personality, Concepts, Cases and Categories, London, Routledge.

Covin, J. G., \& Slevin, D. P. (1991). A conceptual model of entrepreneurship as firm behavior. Entrep. Theory Pract, 16(1), 7-25.

Ellis, T., \& Levy, Y. (2006). A systems approach to conduct and effective literature review in support of Information Systems research. Informing Science, 9, 181-212.

Etemad, H., Richard, W. W., \& Leopaaul, D. (2001). Symbiotic International Business Networks: Collaborative Between Small and Large Firms. Thunder bird International Business Review, 43(4), 481-499.

Gorodnichenko, Yu., Svejnar, J., \& Terrell, K. (2010). Globalization and Innovation in Emerging Markets. American Economic Journal: Macroeconomics, 2(2), 194-226. [Online] Available:http://eml.berkeley.edu/ ygorodni/Innovation_gst.pdf.

Hitt, M. A., Ireland, R. D., \& Hoskisson, R. E. (2001). Strategic Management: Competitiveness and Globalization. 4th edn. Cincinnati: South-Western College Publishing.

Huang, T. (1998). The Strategic Level of Human Resource Management and Organizational Management and Organiational Performance: An Empirical Investigation. Asia Pacific Journal of Human Resources, 36(2), 59-72.

Jalali, S. H. (2012). Export barriers and export performance: Empirical evidence from the commercial relationship between Greece and Iran. South-Eastern Europe Journal of Economics, 1, 53-66.

Kang, S. C., Snell, S. A. (2009). Intellectual Capital Architectures and Ambidextrous Learning: A Framework for Human Resource Management. Journal of Management Studies, 46(1), 65-92. http://web.lib.aalto.fi/fi/oa/db/SCIMA/?cmd=listget\&id=267978\&q=\%40author\%20Kang\%2 C\%20S-C.\&p=1\&cnt=1. [Online] Available: http://www.pogc.ir/portals/0/maghalat/890724-5.pdf

Kumar, D. (2004). Panchayat Raj and Rural Public Libraries in India. In Ramesh Babu, A., \& S. Gopalakrishan (Eds.), Information, Communication and Community Development, 2. Delhi: B.R. Publishing. Pp.497-505

Kuratko, D. K., \& Hodgetts, R. M. (2004). Entrepreneurship: Theory, process \& practice. 6th Edition. United States of America: Thomson South-Western. http: // test. scripts. psu. edu/ users/g/I /gis1/Config MfgStrategy.pdf

Landstrom, A., \& Lois, S. (2005). Entrepreneurship policy: Theory and practice. Birkhauser, Business \& Economics. 
Landstrom, H., \& Johannisson, B. (2001). Theoretical foundationof Swdish entrepreneurship and small-business research. Scandinavian Journal of Management, 17, 225-248.

Leong et al., (1990). G.K. Leong, D. Snyder, P.T. Ward Research in the process and content of manufacturing strategy. Omega, 18, 109-122.

Lumpkin, G. T., \& Dess, G. G. (2006). The effect of Simolicity on the Strategy -performance relationship: a note. Journal of Management Studies, 43(7), 1583-1604.

Luostarinen, R., \& Welch, L. (1990). International Business Operations., Helsinki: Kyriri Oy.

Matanda, M. J., \& Freeman, S. (2009). Effect of perceived environmental uncertainty on exporterimporter inter-organizational relationships and export performance improvement. International Business Review, 18, 89-107.

McCarthy, I. P., Frizelle, G., \& Rakotobe-Joel, T. (2000). Complex systems theory implications and promises for manufacturing organizations. International Journal of Technology Management, 2(1-7), 559-579.

Miller, D. (1983). The Correlates of Entrepreneurship in Three Types of Firms. Management Science 29(7), 770-790. [Online] Available: http://www.olivier-witmeur.net/readings/for-researchers/books-fr?format=pdf

Nelson, W. (2002). The perfect balance for a project portfolio. Baseline, 13, 87.

Nes, Erik B., Carl Arthur Solberg and Ragnhild Silkoset. The Impact of National Culture on Exporter-Distributor Relations. International Business Review, 16, forthcoming.

Perera, S., Harrison, G., \& Poole, M. (1997). Customer-focused manufacturing strategy and the use of operations-based non-financial Performance measures: a research note. Accounting, Organizationa and Society, 22, 557-572.

Pollard, S., \& du Toit, D. (2007). Ecosystems, Protected Areas and People (EPP) Project. UNEP GEF No. GF/27- 13-03-4679. The Regional Protected Areas Programme of IUCN-The World Conservation Union in Asia. IUCN, Bangkok.

Radiguez, C. M., et al. (2013). Strategic capabilities in exporting: an examination of the performance of Mexican firms. Management Decision, 51(8), 1643-1663.

Schaper, M., \& Volery, T. (2004). Entrepreneurship and small business: a Pacific Rim perspective. John Wiley \& Sons Ltd, Milton, Australia.

Solberg, C. A. (1997). A Fremework for Analysis of Strategy Development in Globalization Markets. Journal of International Marketing, (1), 9-30.

Wiklund, J., \& Shepherd, D. (2005). Entrepreneurial orientation and small business performance: a configurational approach. Journal of Business Venturing, 20(1), 71-89.

Zahra, S., A., D. Jennings, F., \& Kuratko, D. F. (1999). The Antecedents and Consequences of 


\section{Macrothink}

Business Management and Strategy

ISSN 2157-6068 2016, Vol. 7, No. 1

Firm-Level Entrepreneurship: The State of the Field. Entrepreneurship Theory and Practice, 24(2), 45 .

Zahra, S. A., \& Nielsen, A. P. (2002). Sources of capabilities, integration and technologycommercialization. Strategic Management Journal, 23, 377-398. [Online] Available:http: / /citeseerx. ist. psu. Edu /viewdoc /download? doi=10.1.1.461.340\&rep=rep1\&type $=$ pdf

\section{Copyright Disclaimer}

Copyright for this article is retained by the author(s), with first publication rights granted to the journal.

This is an open-access article distributed under the terms and conditions of the Creative Commons Attribution license (http://creativecommons.org/licenses/by/3.0/). 